\title{
CORRUPTION IN THE CZECH REPUBLIC IN THE VIEW OF FUTURE MANAGERS
}

\author{
CECHUROVA, L[enka]
}

\begin{abstract}
Presented paper is focused on corruption behaviour in the Czech Republic. Business fields which are affected by such behaviour the most are described based on several researches. Furthermore an own research is presented evaluating perception of corruption from the view of future Czech managers. Results of the research are compared with other researches which are focused on the same topic. At the end of the paper, design of a future research is introduced.

Keywords: Corruption, bribery, business ethics, private-toprivate corruption
\end{abstract}

\section{INTRODUCTION}

Behaviour of economical subjects on market has been judged not only from economical view but from the view of ethical principles lately. Business ethics concerns "usage of fair business practices, dealing in good faith and avoiding of conflict of interest, providing with confidential information and know-how available and also righteousness in relationship with another subjects" [19].

However, enterprises operate in unsTab. dynamic business enviroment also called as competitive enviroment. In such enviroment companies run their business with different goals and strategies. Every company is surrounded with direct as well as indirect competitors, suppliers, customers and other subjects.

As a result of global economic crisis competitive enviroment has become rougher than ever before which in some cases leads to repeated usage of unfair business practices [15]. European Commission defines unfair business practices towards customers in document "The Unfair Commercial Practices Directive" [8].

Company's attitude to business ethics (in relation to customers, suppliers, burreaus and other subjects) can be defined in company's ethical code [4]. Ethical code is "a system of principles governing morality and accepTab. conduct" [21].

Corruption and bribery are in contradiction to business ethics. Corruption is a topic of many papers and studies, however in the Czech Republic the main focus is usually devoted to corruption regarding public sector [23]. An issue that is often discussed is corruption in politics, bureaus and police.

Corruption in private-to-private sector is a little left behind though, which includes the behaviour of business subjects on each other. All this together raises questions that will be answered in this article. The questions are as following:

- How do we define corruption?
- What are the most common types of corruption in the Czech Republic?

- What is the attitude towards corruption of future managers?

- What are the differences in the attitude of present managers and upcoming managers?

\section{CORRUPTION AND BRIBERY}

Corruption could be defined as "abuse of power for personal gain" which includes every corruption regardless of what sector it takes place in. Corruption in public sector is then defined as "abuse of power for illegal personal goals".

United Nations characterizes corruption as "the promising, offering or granting, directly or indirectly, of any undueadvantage in order to induce a public official or any other person to abuse his or her real or supposed influence with a view to obtaining from an administration or a public authority of the State Party any undue advantage or any favourable decisionfor the original instigator of the act or for any other person" [14].

On the other hand offering and recieving has to be distinguished: "For a public official or any other person, the soliciting or accepting, directly or indirectly, of any undue advantage for himself or herself or for another person, through the abuse of his or her real or supposed influence with a view toobtaining from an administration or public authority of the State Party any undueadvantage or any favourable decision for himself or herself or for any other person, whether or not the influence is exerted or whether or not the suppose dinfluence leads to the intended result" [14].

European Commision came up with a list of passive and active corruption (see Tab. 1) based on the background provided by United Nations.

\begin{tabular}{|c|c|c|}
\hline & active corruption & pasive corruption \\
\hline $\mathbf{1}$ & promising, offering or giving & $\begin{array}{l}\text { requesting or receiving or } \\
\text { accepting the promise of }\end{array}$ \\
\hline 2 & \begin{tabular}{|l} 
directly or through an \\
intermediary
\end{tabular} & $\begin{array}{l}\text { directly or through an } \\
\text { intermediary }\end{array}$ \\
\hline 3 & $\begin{array}{l}\text { a person who in any capacity } \\
\text { directs or works }\end{array}$ & $\begin{array}{l}\text { while in any capacity directing } \\
\text { or working }\end{array}$ \\
\hline 4 & for a private-sector entity & for a private-sector entity \\
\hline 5 & $\begin{array}{l}\text { an undue advantage of any } \\
\text { kind }\end{array}$ & an undue advantage of any kind \\
\hline 6 & $\begin{array}{l}\text { for that person or for a third } \\
\text { party }\end{array}$ & for oneself or for a third party \\
\hline 7 & $\begin{array}{l}\text { perform or refrain from } \\
\text { performing any act, in breach } \\
\text { of that person's duties }\end{array}$ & $\begin{array}{l}\text { perform or refrain from } \\
\text { performing any act, in breach of } \\
\text { that person's duties }\end{array}$ \\
\hline
\end{tabular}

Tab. 1 Active and pasive corruption. Source [9] 
Terms bribe and bribery are closely connected to corruption. A bribe is offering, promising, providing, accepting or mediating of an advantage as an incentive for an activity which violates a law [20].

The issue of bribery is covered in legislation of the Czech Republic specifically in criminal code (law $\mathrm{n}$. 40/2009) and also in commercial law (law n. 513/1991) $[2,3]$.

Majority of corruption in private-to-private sector takes place in business connections within sector of merchandise and services, where creating, sustaining and consolidating of personal contacts is most important. Reward (bribe) may be in a form of financial provision, businesslike gift, invitation to social event or an offer of a trip. All the rewards may be requested as well as offered [24].

It has been proven that especially in a business contact it is hard to tell where a proper business ends and corruption behaviour begins. E.g. could an invitation to a dinner be considered as a corruption or as creating good business relationship [17]?

Corruption behaviour in private-to-private sector has lots of negative consequences:

- disturbes of economic competition

- leads to a loss of business opportunities

- decreases return on investment

- can harm consumers

From the view of bribing organization corruption may be helpful, it allows such company to realize business activities which would be without such behaviour uncertain. As a result of it the company may secure its position on the market as well as leverage of its performance $[23,24]$.

\section{CORRUPTION IN THE CZECH REPUBLIC}

Acording to study of SANEP organization, the main problem in the Czech Republic is corruption [26]. Sector that is affected the most is public sector, specifically politics and public procurements. Key current affairs in the Czech Republic are froud and bribery commited by a Members of Parliament [12, 13].

Government of the Czech Republic is aware of this particular situation and tries to improve legislation concerning the problem. During last 2 years government has been coming up with different tools that should eliminate corruption behaviour in both public sector and private-to-private sector. Some of those tools follow:

- all informations about public procurements have to be announced on internet

- operating costs of government are minimized

- electronic auctions can reduce costs of materials, services or energy

- personal audit of all employees in public sector will be more frequent

- punishments for bribery and corruption will be more severe

- implementation of a new form of a budget should help discover pointless costs

- corruption phone number 199 was set due to improve a communication between bureau reposnsible for corruption and people who suspect corruption behaviour in their neighbourhood

- inspection will be set during selling of public properties

- implementation of personal responsibilities for frauds and bribery in corporations [11]

In private-to-private sector the most common corruption affairs are in civil engineering field. This fact declares newspaper articles $[1,6,16,18,19]$.

All the information mentioned above are reflecting the position of the Czech Republic in Corruption Perception Index (CPI). In 2008, 45 ${ }^{\text {th }}$ place in CPI belonged to the Czech Republic. Unfortunately, during next 3 years position of the Czech Republic has been slumping down to $57^{\text {th }}$ position [10].

During the economic crisis, companies have been more tolerant to unfair practices. The main reason of this particular situation is a tough struggle with competition and decline of demand. According to Ernst\&Young research more than $50 \%$ of Czech companies stated that corruption or unfair behaviour is accepTab. as long as it helps them to "survive" [6].

\section{EMPIRICAL RESEARCH}

The research focuses on opinions of students of Faculty of Economics in study program Economics and Management in Pilsen. Students in particular field have been chosen on purpose because they have no real working experience in managerial positions (but soon expected to be) and therefore their opinions may greatly differ from the point of view of skillful managers who may have already experienced corruption behaviour.

Since the main objective of this paper is an analysis of opinions of future managers, an online survey was chosen to gather all the data. The questionnaire was made and distributed using Google Documents Form, it consisted of 20 questions. A testing period was held before the research to verify clarity of questions. Then the research itself took place in June and September 2012 .

Basics characteristics of target group are illustrated in Tab. 2. Age and sex distribution represents the characteristics of all faculty fulltime students.

\begin{tabular}{|c|c|c|c|c|c|c|c|}
\hline $\begin{array}{c}\mathrm{N} \\
\text { (total) }\end{array}$ & males & females & $\begin{array}{c}\text { median } \\
(\text { age })\end{array}$ & $\begin{array}{c}\text { average } \\
\text { (age) }\end{array}$ & $\begin{array}{c}\text { min } \\
\text { (age) }\end{array}$ & $\begin{array}{c}\text { max } \\
\text { (age) }\end{array}$ & $\begin{array}{c}\text { SD } \\
\text { (age) }\end{array}$ \\
\hline 182 & 43 & 139 & 21 & 21,763 & 19 & 27 & 1,556 \\
\hline
\end{tabular}

Tab. 2. Targed group characteristics. Source own, 2012

\section{RESULTS}

Out of the total amount of respondents all of them are aware of the word corruption and its meaning. More than $83 \%$ of respondents believe that corruption in the Czech Republic is widely spreaded. This fact confirms that in the view of students corruption is a present problem that needs to be dealt with. Over $90 \%$ claims that corruption behavior is commonly used in public procurements and $82 \%$ believe it happens within communication with bureau.

$61 \%$ of students believe that sector with highest presence of corruption in Private-to-private sector is civil 
engineering. Such situation within the civil engineering sector has been confirmed by CEEC Research Company [5], which stated that more than $41 \%$ of companies were requested for a bribe. Students placed second in privateto private sector retail with $39 \%$ than finacial institution with $24 \%$ and $7 \%$ in tourism.

Respondents are aware of business ethics, which is declared by answers to questions considering a model situation. First situation is from the view of consumer. Only $18 \%$ of respondents would continue in purchase of good from a company that is known for bribery.

Another question considers the manager's point of view. Only $13 \%$ of respondents stated that they would't quit doing business with a partner known for bribery. Furthermore, no more than $4 \%$ of students believe that bribere could be excused by gaining a new contract.

These results are supported by general opinion that honest player reputation may become a competitive advantage. Students supported this opinion in more than $70 \%$ which is approximatelly the same as belief of European managers. On the other hand only 37\% of Czech managers think that honest player reputation can result some benefits [6].

Respondets are also aware of an existance of unfair comercial practices directive and its application in Czech law system. According to results over $56 \%$ of respondents faced some unfair business practice. But only one quarter of these respondents reported that particular situation to police or other authority. This should be explained by other fact, that arise from results - over $40 \%$ of all respondents do not know where they should report these practices.

Respondents also stated that agressive practices towards customers which are defined in black list are unethical and should be strictly punnished.

Behaviour, which is in contrary with business ethic, should be penalized. Respondents agreed that managers, CEO, board of directors and other management staff should have personal responsibilities for frauds and bribery.

On the other hand, present situation on the market where companies fight each other for every costumer or contract doesn't create conditions for fair-play. Approximately half of the respondents stated that business ethics codes have to be put aside when company's existence is threatened. This result is the same as the Ernst\&Young research [6].

Respondents'opinions on question concerning other than financial provision bribes differs. Even though three quarters of students find a gift for less than $10,000 \mathrm{Czk}$ as a bribe, less than $42 \%$ of managers believe so.

Opinions of both groups on financial provision are approximately same. The comparison of those two groups is illustrated in Fig. 1.

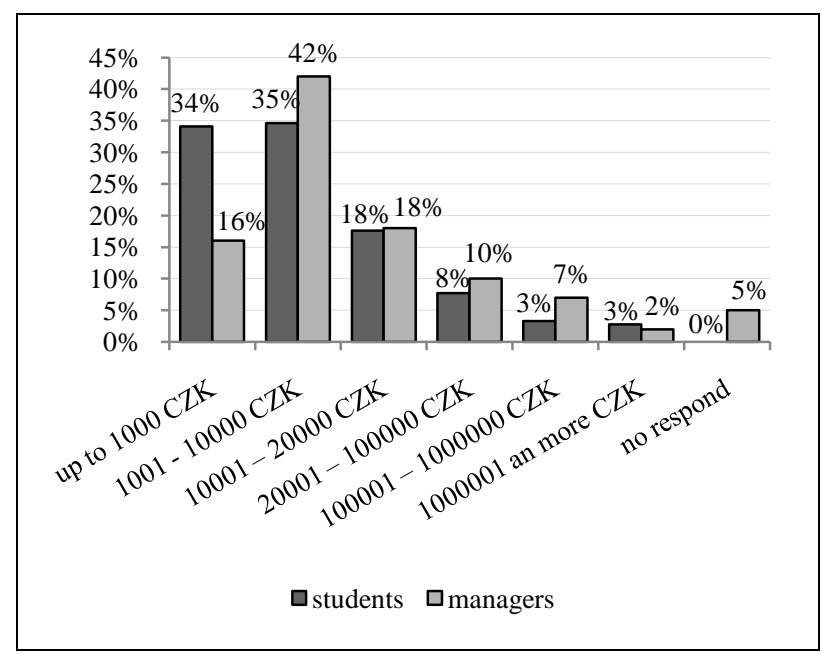

Fig. 1. Comparison of opinions about financial provision. Source own, 2012

The biggest difference betweet managers and student is financial provision up to $1,000 \mathrm{Czk}$. This result is based on value of money. For managers, 1,000 Czk is just a small part of their income; on the other hand students consider same amout of money as significan part of their budget.

Cumulative summation of results show that majority of students $(86,3 \%)$ belives that every amount of money up to $20,000 \mathrm{Czk}$ is a bribe while $86 \%$ of managers states that bribe is amout of money up to $100,000 \mathrm{Czk}$.

\section{RESEARCH LIMITATIONS}

Presented research shows that current college students of Economics and Management are aware of business ethics and corruption behaviour.

The main limitation of this research is number of respondents and also that majority of respondents live in the same Bohemian region. Some characteristic of the sample such as number of respondents and region where respondents live should be improved in future research.

In presented research, distribution of gender reflects distribution of Faculty students (23,7\% male and $76,3 \%$ female), but does not reflects gender distribution of managers.

That is why future research should take into consideration real gender distribution. Therefore if a future research is about to take place it would be conveniet to extend it to the whole Czech Republic and try to obtain such gender distibution that would correspond with true distribution.

\section{CONCLUSION}

Corruption within economical subjects is existing, unwanted and hardly traceable occurrence, which has many negative effects on functioning and quality of business environment. Economical subject may defend themselves by intensified pressure on government and legislation.

Willingness to adopt anticorruption set of rules from the side of companies supports proper business transactions between companies as well as between companies and public sector. This also leads to increased quality of business environment. During such activities 
companies may use principles recommended by relevant international organizations.

These days corruption has been the main issue in politics as well as in private-to-private sector in the Czech Republic, offering or requesting of a bribe is the most frequently used type of corruption.

Presented research indicates that future managers show a real promise to business ethics because majority of them disapprove of unfair practices in busines-tobusines sector or towards customers.

Based on the results obtained from the research made, it may be stated that future generation of managers has a strong aversion towards any kind of corruption behaviour.

\section{REFERENCES}

[1] Biskup, P. (2010). Police arrested Managers of civil engineering Company with a Bribe worth Millions (Policisté zatkli manažery stavební firmy $\mathrm{s}$ milionovým úplatkem). Available from: http://www.novinky.cz/krimi/204947-policiste-zatkli-manazerystavebni-firmy-s-milionovym-uplatkem.html Accessed on: 2012$09-26$

[2] BusinessCenter.cz. (2012). Commercial Law (Obchodní zákoník). Available http://business.center.cz/business/pravo/zakony/obchzak/ Accessed on: 2012-09-28

[3] BusinessCenter.cz. (2012). Criminal Code (Trestní řád). Available from: http://business.center.cz/business/pravo/zakony/trestni_rad/ Accessed on: 2012-09-26

[4] BusinessInfo. (2012). Business Morality and Ethics, Psychology of financial Trades (Podnikatelská morálka a etika, psychologie finančních trhů.) Available from: http://www.businessinfo.cz/cs/clanky/podnikatelska-moralka-aetika-psycholog-3738.html Accessed on: 2012-10-15

[5] CEEC Research, (2011) Qualitative Study of Czech Civil Engineering (Kvalitativní studie českého stavebnictví). Available from: http://www.ceeconstruction.eu/download.php Accessed on: 2012-09-28

[6] Ernst\&Young. (2009). Frauds on rise in european Companies during Crisis (Podvodův se v evropských společnostech během krize daří). Available from: http://www.ey.com/CZ/cs/ Newsroom/News-

releases/2009_05_Evropsky_pruzkum_o_podvodech Accessed on: $2012-09-27$

[7] Europa.eu. (2012). United Nations Agreement on Fight against Fraud (Úmluva Organizace spojených národů o boji proti korupci). Available from: http://europa.eu/legislation_summaries/fight_against_fraud/fight_ against_corruption/133300_cs.htm Accessed on: 2012-09-29

[8] European Commission. (2006) Unfair Commercial Practise Directive. Available from: http://ec.europa.eu/consumers/cons_int/safe_shop/fair_bus_pract/ ucp_en.pdf Accessed on: 2012-10-15

[9] European Commission. (2007). Member States fail to Implement EU Legislation to combat Corruption in the private Sector. Available

from: http://europa.eu/rapid/pressReleasesAction.do?reference=IP/07/84 $8 \&$ format $=$ HTML\&aged $=0$ \&language $=\mathrm{EN} \&$ guiLanguage $=\mathrm{en}$ Accessed on: 2012-09-26

[10] Gola, P. (2012). Czech Republic failed in Corruption Perception Index (Česko padá v Indexu korupce žebříčkem dolů). Available from: http://www.finance.cz/zpravy/finance/338447-cesko-padav-indexu-korupce-zebrickem-dolu/ Accessed on: 2012-09-28

[11] Government informational Center (Informační centrum vlády). (2012). Anti-corruption precaution (Protikorupční opatření). Available from: http://icv.vlada.cz/cz/protikorupcni-opatreni/ Accessed on: 2012-09-29

[12] Ihned.cz. (2012). Who gave Information away on Parkanova Prosecution? Inspection found nothing, Case is put on hold. (Kdo prozradil chystané stíhání Parkanové? Inspekce nic nezjisila, př́pad odložila). Available from: http://zpravy.ihned.cz/cesko/c1- 57020160-kdo-prozradil-chystane-stihani-parkanove-inspekcenic-nezjistila-pripad-odlozila Accessed on: 2012-09-28

[13] Ihned.cz. (2012). Rath introduced his Proposal on Prisoners Condition changes. (Rath zveřejnil svůj návrh na změnu podmínek pro vězně - mají mít obchod i mobil). Available from: http://zpravy.ihned.cz/politika/c1-57376560-rath-zverejnil-svujnavrh-na-zmenu-podminek-pro-vezne-maji-mit-obchod-i-mobil Accessed on: 2012-09-27

[14] Institute of Crime and social Prevention (Institut pro kriminologii a sociální prevenci). (2008). Documents of UN concerning Corruption and organized Crime (Dokumenty OSN ke korupci a organizovanému zločinu: Úmluva OSN proti korupci). Available from: www.ok.cz/iksp/docs/341.pdf Accessed on: 2012-09-29

[15] Ipodnikatel.cz. (2012). Is there any Place for business Ethics? (Etika v podnikání - má ještě vůbec své místo?). Available from: http://www.ipodnikatel.cz/O-podnikani-obecne/etika-vpodnikani-ma-jeste-vubec-sve-misto-pod-sluncem.html Accessed on: 2012-10-15

[16] Kreuzerová, B. (2011). Corruption in Czech Civil Engineering rises. Public Procurements Law is weak (Korupce v tuzemském stavebnictví kvete. Zákon o veřejných zakázkách je na ni zatím krátký). Available from: http://www.rozhlas.cz/zpravy/politika/_zprava/894318 Accessed on: 2012-09-26

[17] Kunešová, H. (2011). Selected Issues of private-to-private Corruption (Vybrané otázky korupce v soukromém sektoru), Proceedings of Trendy v podnikáni 2011, Business Trends, Pilsen, ISBN 978-80-261-0055-3, Cimler, P. (Ed.), pp. 47-52, ZČU v Plzni, 2011

[18] ManagerWeb.cz. (2010) Bribes - common Problem of Czech Civil Engineering and Mechanical Engineering (Úplatky - stálý problém českého stavebnictví a strojírenství). Available from: http://financnimanagement. ihned.cz/c1-46506220 Accessed on: 2012-09-29

[19] Mašek, F. (2011). Bribe in order to get public Procurement? Sixteen Percent of its Value (Úplatek za získání veřejné zakázky? Šestnáct procent její hodnoty). Available from: http://www.penize.cz/statni-rozpocet/209609-uplatek-za-ziskaniverejne-zakazky-sestnact-procent-jeji-hodnoty Accessed on: 2012-09-28

[20] Radaikin, A. (2011). Good Manners and economic Competition (Dobré mravy a hospodářská soutěž). Acta Oeconomica Pragensis. Available from: www.vse.cz/polek/download.php?.jnl=aop\&pdf=325.pdf Accessed: 2012-10-01

[21] The Free Dictionary. (2012). Ethical Code. Available from: http://www.thefreedictionary.com/ethical+code Accessed: 201210-15

[22] Transparency International. (2009). Business Principles of countering Bribery. $\quad$ Available from: http://www.transparency.org/whatwedo/tools/business_principles _for_countering_bribery Accessed on: 2012-09-28

[23] Transparency International Czech Republic. (2006). Aplication of Tools and Techniques in business Ethics in Czech Republic (Aplikace metod a nástrojů podnikatelské etiky $\mathrm{v}$ českém podnikatelském prostředí). Available from: http://www.transparency.cz/doc/ve_amanpe.pdf Accessed on: 2012-10-15

[24] Transparency International Czech Republic. (2006). Ethical Approach in Business (Etické prístupy v podnikání). Available from:

http://www.transparency.cz/doc/ve_eticke_pristupy_vpodnikani.p df Accessed on: 2012-09-29

[25] Trnková, J. (2011). Civil Engineering in Czech Republic: Public Procurement with no Bribe? Almost impossible (Stavebnictví v Česku: Veřejné zakázky bez úplatku? Téměř nemožné!) Available from: http://www.realitymorava.cz/realitni-zpravodaj/391stavebnictvi-v-cesku-verejne-zakazky-bez-uplatku-temernemozne Accessed on: 2012-09-28

[26] Zajíc, O. (2012). SANEP: Corruption in Czech Republic is a real Threat to Democracy according to Czech Majority (SANEP: Korupce v ČR vážně ohrožuje demokracii, míní většina Čechů). Available from: http://www.protext.cz/zprava.php?id=14060 Accessed on: 2012-09-26 